\title{
Research on Energy Storage Cost Model in Distributed Energy System Environment
}

\author{
Shuo Yin ${ }^{1}$, Zhe $\mathrm{Chai}^{1}$, Xing Chen ${ }^{1}$, Meng Yang ${ }^{1}$, Yao $\mathrm{Lu}^{1,}{ }^{*}$, Kyle Georgiou ${ }^{2}$ \\ ${ }^{1}$ State Grid Henan Economic Research Institute, Zhengzhou, China \\ ${ }^{2}$ University of Waterloo, Canada
}

\begin{abstract}
With the "dual carbon" goal proposed and the direction of building a new power system dominated by new energy sources clarified, the energy storage industry has entered the fast lane of accelerated development. However, due to the imperfect marketization mechanism and the lack of effective power market ancillary service policies, it is difficult to 00EFfectively recover the cost of energy storage construction, which restricts the development of the energy storage industry to a certain extent. Therefore, it is urgent to clarify the development trend and cost recovery mechanism of typical types of energy storage under the distributed energy system, and clarify the impact of the operating cost of the electrochemical energy storage system. This paper systematically analyses the domestic and foreign energy storage investment channelling mechanisms, clarifies the impact of energy storage cost system operation on costs, and helps the development of the energy storage industry.
\end{abstract}

Keywords: Electrochemical energy storage; Cost of investment; Grooming mechanism.

\section{Preface}

Energy storage investment cost diverting mechanism. From the perspective of international practices, energy storage applications in the United States, Europe, Australia, Japan and other regions are relatively active, mainly distributed energy storage, and mainly support the development of energy storage system through incentive policies and market mechanism design, to help users reduce electricity prices, increase the proportion of renewable energy utilization, and improve power quality or disaster recovery capabilities. From the perspective of domestic policies, the status of energy storage in the energy system and industrial development is gradually established. At the local level, local policies have been introduced to promote the development of the energy storage industry in terms of grid operation, auxiliary services, demand-side response, and subsidy mechanisms. In general, energy storage should use market-based methods to recover costs as much as possible.

\section{The impact of electrochemical energy storage system operating costs}

The influencing factors of the charge-discharge cycle cost of electrochemical energy storage equipment are mainly related to DOD and discharge efficiency. First discuss the relationship between cycle cost and DOD. It should be clear that the relationship between cycle cost and DOD is related to the initial state of the SOC and the end state of the SOC cycle of the electrochemical energy storage system. For example, there are two situations: (1) SOC is discharged from $100 \%$ to $40 \%$; (2) SOC is discharged from $80 \%$ to $20 \%$. Although the DOD of the depth of discharge of the two types of cases is $60 \%$, the cycle cost in the case of type (2) is obviously higher.Therefore, this example also confirms from the side that one of the variables in the operation model of the energy storage system is SOC instead of DOD.

The second factor that affects the cycle cost of an electrochemical energy storage battery is the high current intensity in the state of charge and discharge. The following formula reflects the discharge efficiency of the battery through the DCR variable, and the physical meaning is expressed as the SOC change per unit time:

$$
D C R_{t}=\frac{S O C_{t-1}-S O C_{t}}{T}=\triangle S O C_{t}
$$

The discharge efficiency of an energy storage battery can be represented by " $\mathrm{C}$ ". For example, $1 \mathrm{C}$ means that the battery is fully discharged within 1 hour, $2 \mathrm{C}$ means that the battery is fully discharged within half an hour, $3 \mathrm{C}$ means that the battery is fully discharged within 20 minutes, and so on.In order to accurately establish the relationship between the loss model of the electrochemical energy storage battery and the DOD and discharge efficiency, the following Figure 1 shows the relationship between the cycle period of the lithium ion battery and the DOD (at a given temperature and discharge efficiency):

* Corresponding author: luyao@ha.sgcc.com.cn 


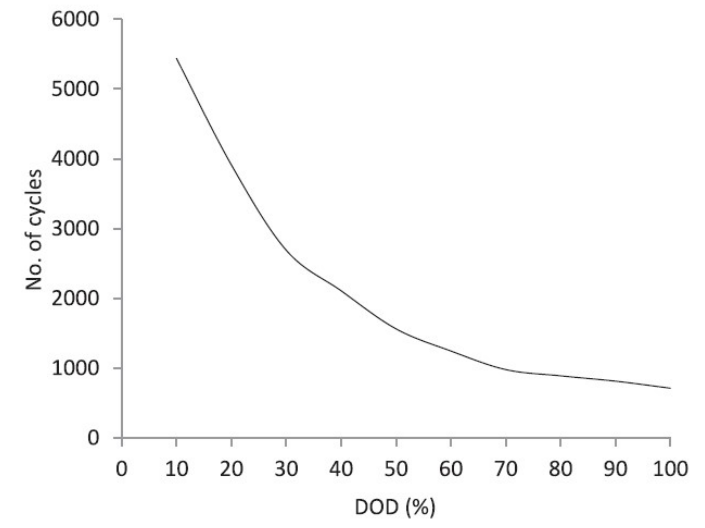

Figure 1 The relationship curve between the cycle period of lithium battery and DOD

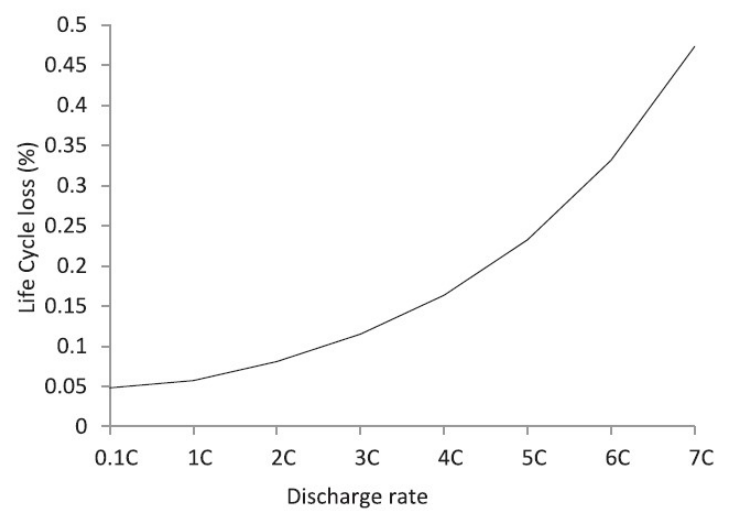

Figure 2 Lithium battery cycle life loss and discharge efficiency curve

Through the relationship curve in Figure 1, the mathematical expression of the relationship between the cycle period of the lithium battery and the DOD can be obtained:

$$
L(D)=\gamma D^{-\omega}
$$

In the above formula, $\gamma, \omega$ is a parameter of the mathematical relationship between the number of cycles and the DOD in the case of a lithium battery $1 \mathrm{C}$ discharge efficiency.

Similarly, the relationship between cycle life loss and discharge efficiency of a lithium battery is shown in Figure 2. It can be found that in the range of discharge efficiency below $3 \mathrm{C}$, the relationship between cycle life loss and discharge efficiency is close to linear.Combining the information in Fig. 1 and Fig. 2, the relationship curve between the cycle period and the DOD under different discharge efficiencies can be obtained, as shown in Fig. 3.

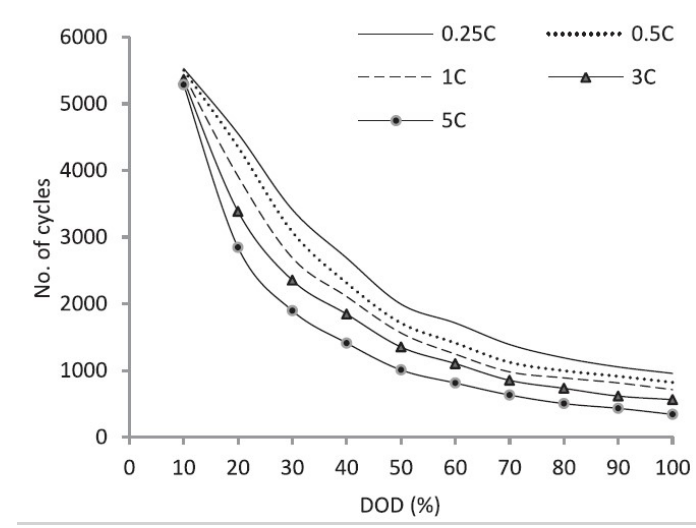

Figure 3 Cycle period under different discharge efficiency



Figure 4 Cycle cost under different DOD and discharge efficiency Relationship curve with DOD

Considering the SOC for the start and stop of the energy storage battery, the mathematical expression of the cycle cost at a certain discharge efficiency is as follows:

$$
C 1_{t}=\frac{C^{B}}{B_{c a p}^{E} \eta^{2} \gamma}\left[\left(1-S O C_{t}\right)^{\omega}-\left(1-S O C_{t-1}\right)^{\omega}\right]
$$

In the formula, $C^{B}$ is the construction cost of energy storage, $B_{\text {cap }}^{E}$ is the rated capacity of the energy storage system, and $\eta$ is the cycle efficiency of the energy storage cycle. Based on the above formula, for different discharge efficiencies and different values of $S O C_{t}$ and $S O C_{t-1}$, the cycle cost of the energy storage battery can be represented by Figure 4.Note that the cyclic cost function is a non-linear function, which is difficult to apply to the market optimization model. Linear simplification processing is required for the cyclic cost model. The linear simplification results are as follows:

$$
C 1_{t}=a S O C_{t}+b S O C_{t-1}+c D C R_{t}+d
$$

In the formula, a, b, c, d are the coefficients of the battery cycle cost model. 


\section{Incentive Grooming Mechanism}

Incentive policies in the United States are mainly geared towards user-side distributed energy storage. The United States has formulated a self-generation incentive plan. For energy storage equipment, the installed power subsidy will be provided at the standard of US $\$ 2 / \mathrm{W}$ before 2016 . After 2016, the power generation subsidy will be granted according to the installed capacity. There are five stages. The subsidy amount for the first stage is 0.5 to 0.6 $\mathrm{USD} / \mathrm{Wh}$, and thereafter, each stage will be reduced by $0.05 \mathrm{USD} / \mathrm{Wh}$.

Table 1. The subsidy standards for the five rounds of subsidies in the 2017 edition of the SGIP manual

\begin{tabular}{|c|c|c|c|c|c|}
\hline Energy storage project & \begin{tabular}{|c} 
First \\
round \\
\$ $\$(\mathrm{~W} \cdot \mathrm{h})$
\end{tabular} & $\begin{array}{l}\text { Second } \\
\text { round } \\
/ \$ \text { (W.h) }\end{array}$ & $\begin{array}{l}\text { Third } \\
\text { round } \\
\text { \$S.(W.h })\end{array}$ & $\begin{array}{l}\text { Forth } \\
\text { round } \\
/ \$(\mathrm{~W} \cdot \mathrm{h})\end{array}$ & $\begin{array}{l}\text { Fifth } \\
\text { round } \\
\text { \$S.(W.h }\end{array}$ \\
\hline \begin{tabular}{|c|c|}
\multicolumn{2}{|c|}{ Large-scale } \\
energy storage $(>10 \mathrm{kw})$
\end{tabular} & 0.5 & 0.4 & 0.35 & 0.3 & 0.25 \\
\hline $\begin{array}{c}\text { Obtain ITC's } \\
\text { large-scale energy storage }\end{array}$ & 0.36 & 0.29 & 0.25 & 0.22 & 0.18 \\
\hline $\begin{array}{c}\text { Home energy storage } \\
(\leqslant 10 \mathrm{kw})\end{array}$ & 0.5 & 0.4 & 0.35 & 0.3 & 0.25 \\
\hline
\end{tabular}

Germany's incentive policies are mainly for distributed optical storage. Its subsidy policy lasted for 6 years. Since 2013, the subsidy policy for photovoltaic storage has mainly provided $30 \%$ of the investment amount of household energy storage equipment, and provided lowinterest loans to units or individuals purchasing photovoltaic energy storage equipment. The photovoltaic energy storage system grants a subsidy of up to 600 Euros $/ \mathrm{kW}$.
Table 2. List of subsidy policies of German optical storage.

\begin{tabular}{|c|c|c|c|}
\hline \begin{tabular}{|c|} 
release \\
time
\end{tabular} & $\begin{array}{c}\text { Subsidy } \\
\text { object }\end{array}$ & $\begin{array}{l}\text { Condition } \\
\text { requirements }\end{array}$ & Subsidy standard \\
\hline $\begin{array}{c}\text { March } \\
2013\end{array}$ & \begin{tabular}{|c|} 
Energy \\
storage \\
system \\
supporting \\
household \\
photovoltaic
\end{tabular} & $\begin{array}{l}\text { The peak power } \\
\text { of photovoltaics is } \\
\text { below } 20 \mathrm{~kW} \text {; only } \\
\text { up to } 60 \% \text { of the } \\
\text { photovoltaic } \\
\text { power generation } \\
\text { can be sent to the } \\
\text { grid; the energy } \\
\text { storage system } \\
\text { has a } 7 \text {-year } \\
\text { warranty. }\end{array}$ & $\begin{array}{c}30 \% \text { of subsidies } \\
\text { for the installation } \\
\text { of energy storage } \\
\text { systems; newly } \\
\text { installed } \\
\text { photovoltaic } \\
\text { energy storage } \\
\text { systems are given } \\
\text { a subsidy of up to } \\
600 \text { Euros } / \mathrm{kWp} .\end{array}$ \\
\hline $\begin{array}{c}\text { March } \\
2016\end{array}$ & $\begin{array}{c}\text { The object } \\
\text { of funding } \\
\text { is a } \\
\text { stationary } \\
\text { battery } \\
\text { energy } \\
\text { storage } \\
\text { system (not } \\
\text { a } \\
\text { photovoltaic } \\
\text { device) that } \\
\text { matches } \\
\text { photovoltaic } \\
\text { equipment, } \\
\text { and only } \\
\text { one battery } \\
\text { energy } \\
\text { storage } \\
\text { system that } \\
\text { matches } \\
\text { photovoltaic } \\
\text { equipment } \\
\text { can be } \\
\text { subsidized }\end{array}$ & $\begin{array}{l}\text { The photovoltaic } \\
\text { system with } \\
\text { energy storage } \\
\text { battery must be } \\
\text { installed after } \\
\text { December } 2012 \text {, } \\
\text { and the peak } \\
\text { power cannot } \\
\text { exceed 30kWp; } \\
\text { the power fed } \\
\text { back by the } \\
\text { photovoltaic } \\
\text { system to the grid } \\
\text { cannot exceed } \\
50 \% \text { of the peak } \\
\text { power; the system } \\
\text { service life must } \\
\text { be at least } 20 \\
\text { years; the battery } \\
\text { system must Have } \\
\text { a } 10 \text {-year } \\
\text { warranty; } \\
\text { installers must } \\
\text { have relevant } \\
\text { qualifications. }\end{array}$ & $\begin{array}{c}\text { Depending on the } \\
\text { year of } \\
\text { application, } \\
\text { The proportion of } \\
\text { subsidies } \\
\text { provided by banks } \\
\text { is also different; } \\
2016 / 3 / 1- \\
2016 / 6 / 30 \text { : The } \\
\text { loan subsidy ratio } \\
\text { is } 25 \% \text {; } \\
2016 / 7 / 1- \\
2016 / 12 / 31 \text { : The } \\
\text { loan subsidy ratio } \\
\text { is } 22 \% \text {; } \\
2017 / 1 / 1- \\
2017 / 6 / 30 \text { : The } \\
\text { loan subsidy ratio } \\
\text { is } 19 \% \text {; } \\
2017 / 7 / 1- \\
2017 / 9 / 30: \text { loan } \\
\text { subsidy ratio } \\
16 \% ; 2017 / 10 / 1- \\
2017 / 12 / 31: \text { loan } \\
\text { subsidy ratio } \\
13 \% ; 2018 / 1 / 1- \\
2018 / 12 / 31: \text { loan } \\
\text { subsidy } 10 \% \text {; }\end{array}$ \\
\hline
\end{tabular}

Japan's incentives are mainly for residential use of energy storage systems. Energy storage incentive policies are mainly used to alleviate the grid management challenges brought about by a large number of distributed solar energy, which has also increased the demand for battery energy storage systems. Since 2018, the Ministry of Economy, Trade and Industry of Japan has invested about 98.3 million U.S. dollars to provide $66 \%$ of the cost subsidy for families and businesses that install lithium electronic batteries. So far, Japanese government subsidies can account for $40-50 \%$ of the entire battery retail price. 


\section{Market-oriented Governance Mechanism}

In the United States, FM ancillary services are the main form of energy storage participating in the market. The Federal Energy Regulatory Commission (FERC) issued Decree No. 841 in 2018, requiring all electricity markets to allow energy storage to participate in the wholesale electricity market, ancillary service market, and capacity market. From a practical point of view, the FM auxiliary service market is currently the most important form of participation in energy storage. $76 \%$ of electrochemical energy storage in the United States participates in power frequency modulation auxiliary services. The California Independent Operator (CAISO) has the most outstanding performance in this regard, and can participate in the dayahead FM market through the non-generation resource model (NGR).

In Germany, a higher frequency market bidding model is used to achieve revenue stacking. The German Federal Power Grid Administration has optimized the bidding time and the minimum bid size for the second and third frequency modulation. Starting from July 2018, the bidding time for the second frequency modulation and the third frequency modulation has been changed from weekly to daily. The supply time period has also been changed from " 2 segments per day, 12 hours per segment" to "6 segments per day, 4 hours per segment". Highfrequency bidding and a shorter service supply window allow energy storage capacity to participate in more target markets, and can more effectively stimulate aggregate energy storage capacity to achieve revenue stacking.

In Australia, independent ancillary service providers can directly participate in the market. The Australian Energy Market Commission (AEMC) issued the "National Electricity Modification Rules" to open ancillary services to new market participants, namely, market-oriented ancillary service providers other than large power generation companies. Market participants can provide ancillary services at one location, or aggregate loads or units from multiple locations to provide services. Since the implementation of this rule in 2017 , it has greatly increased the opportunities for energy storage to participate in the Australian power ancillary service market.

\section{Concluding remarks}

The United States, Europe, Japan and other countries generally introduced direct fiscal and taxation measures such as initial investment subsidies, tax reductions and exemptions. At the same time, they also actively guide energy storage to participate in power market transactions, and "two-pronged" support energy storage development. Domestic energy storage diversion is mainly through government regulation and diversion, including the successive introduction of local policies to promote the development of the energy storage industry in terms of grid operation, auxiliary services, demand-side response and subsidy mechanisms.

The core products of energy storage are electric and electricity. From the perspective of pricing mechanism, its price policy is related to function positioning and operation mode. The diversification of its functions and operating models determines the diversification of its investment recovery channels and pricing diversification. In principle, energy storage should adopt market-based methods as much as possible to recover costs.

\section{Acknowledgments}

This work was supported by the Science and Technology Project of SGCC, Research on the competition situation and operation mode of distribution companies in the park (52170018000S).

\section{References}

1. Analytical method for estimating leakage of reservoir basins for pumped storage power stations[J], Bulletin of Engineering Geology and the Environmen, 2021. PP 1-14.

2. Safety warning of lithium-ion battery energy storage station via venting acoustic signal detection for grid application[J], Journal of Energy StorageVolume 38, 2021.

3. Competitive model of pumped storage power plants participating in electricity spot Market__ in case of China[J], Renewable EnergyVolume 173, 2021. PP 164-176.

4. Atomic layer deposition in the development of supercapacitor and lithium-ion battery devices[J], CarbonVolume 179, 2021. PP 299-326.

5. Use of Energy Storage in Low Thrust Spaceflight[J], Critical Asian StudiesVolume 30, Issue 1. 2012.

6. Design and Test of Controller in Power Conditioning System for Superconducting Magnetic Energy Storage[J],ICPE(ISPE) symposium 2007. PP 966970 . 